\title{
SYNTHESIS, CHARACTERIZATION, ANTIBACTERIAL AND ANTIFUNGAL STUDIES OF SOME TRANSITION AND RARE EARTH METAL COMPLEXES OF N-BENZYLIDENE-2-HYDROXYBENZOHYDRAZIDE
}

\author{
V.A. Shelke ${ }^{1}$, S.M. Jadhav ${ }^{1}$, S.G. Shankarwar ${ }^{1}$, A.S. Munde ${ }^{2}$ and T.K. Chondhekar ${ }^{1 *}$ \\ ${ }^{1}$ Department of Chemistry, Dr. Babasaheb Ambedkar Marathwada University, \\ Aurangabad-431 004, India \\ ${ }^{2}$ Department of Chemistry, Milind College of Science, Aurangabad-431 004, India
}

(Received September 28, 2010; revised February 16, 2011)

\begin{abstract}
The solid complexes of $\mathrm{Cu}$ (II), $\mathrm{Co}$ (II), $\mathrm{Mn}$ (II), $\mathrm{La}$ (III) and $\mathrm{Ce}(\mathrm{III})$ were prepared from bidentate Schiff base, N-benzylidene-2-hydroxybenzohydrazide. The Schiff base ligand was synthesized from 2hyhdroxybenzohydrazide and benzaldehyde. These metal complexes were characterized by molar conductivity, magnetic susceptibility, thermal analysis, X-ray diffraction, FTIR, ${ }^{1} \mathrm{H}-\mathrm{NMR}, \mathrm{UV}-\mathrm{Vis}$ and mass spectroscopy. The analytical data of these metal complexes showed metal:ligand ratio of 1:2. The physico-chemical study supports the presence of square planar geometry around $\mathrm{Cu}$ (II) and octahedral geometry around $\mathrm{Mn}$ (II), $\mathrm{Co}$ (II), $\mathrm{La}$ (III) and $\mathrm{Ce}(\mathrm{III})$ ions. The IR spectral data reveal that the ligand behaves as bidentate with ON donor atom sequence towards central metal ion. The molar conductance values of metal complexes suggest their non-electrolyte nature. The X-ray diffraction data suggest monoclinic crystal system for these complexes. Thermal behavior (TG/DTA) and kinetic parameters calculated by Coats-Redfern method are suggestive of more ordered activated state in complex formation. The ligand and their metal complexes were screened for antibacterial activity against Staphylococcus aureus and Escherichia coli and fungicidal activity against Aspergillus niger and Trichoderma.
\end{abstract}

KEY WORDS: Bidentate Schiff base, Metal complexes, Thermal analysis, XRD, Antimicrobial study

\section{INTRODUCTION}

There has been growing interest in the study of hydrazones because of their physiological activity, coordinative capability, and applications in analytical chemistry [1,2]. Compared to the simple hydrazone Schiff bases, aroyl or heteroaroyl Schiff bases have additional donor sites. This introduces a wider range of properties for these substances. The study of ligands involving such hydrazones is interesting as they demonstrate versatility in coordination, a tendency to yield stereochemistry [3] of higher coordination number, an ability to behave as neutral or deprotonated ligands, and flexibility in assuming different conformations. Recently, several metal complexes of Schiff bases containing N,S and N,O donors have been synthesized and studied [4-6]. This may be due to the reported anticarcinogenic and antiviral activity of these donor ligands and the complexes obtained from them [7, 8]. A number of hydrazone derivatives have interesting bioactivity towards anti-bacterial, anti-fungal [9], anti-convulsant [10], antiinflammatory [11], anti-malarial [12, 13], analgesic [13], anti-platelets [14], anti-tuberculosis [15], and anti-cancer activities [16]. Hydrazones also act as herbicides, insecticides, nematocides, rodenticides, and plant growth regulators and are used as plasticizers, stabilizers and antioxidant initiators for polymerization [17]. Hydrazone derivatives are used in analytical chemistry as selective metal extracting agents as well as in the spectroscopy for the determination of certain transition metals [18].

It was thought worth while that the metal complexes formed by the combination of transition metal ion with a potent hydrazone Schiff base ligand should be more biologically active than the metal salts or the ligand individually. Therefore, we report here the synthesis and characterization of $\mathrm{Cu}(\mathrm{II}), \mathrm{Co}(\mathrm{II}), \mathrm{Mn}$ (II) $\mathrm{La}(\mathrm{III})$ and $\mathrm{Ce}(\mathrm{III})$ complexes with 1-(2-

*Corresponding author. E-mail: tkcchem@gmail.com 
hydroxybenzamido)-2-(2-methylphenyl)-azomethin. The anti-fungal and anti-bacterial properties of the ligand and its metal complexes were also tested.

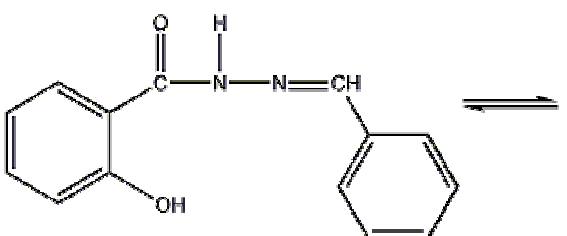

Keto form

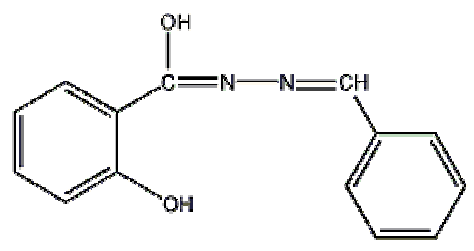

Enol form

Figure 1. Keto and enol form of ligand.

\section{Materials}

EXPERIMENTAL

All the chemicals used were of the analytical grade (AR) and of highest purity. Methyl 2hydroxybezoate, hydrazine and benzaldehyde were purchased from E-Merck (AR grade) and were used for synthesis of ligand. AR grade metal chlorides of S.D. Fine chemicals were used for complex preparation. Spectral grade solvents were used for spectral measurements. The carbon, hydrogen and nitrogen contents were determined on Perkin Elmer (2400) CHNS analyzer. IR spectra for ligands and metal complexes were recorded on Jasco FT-IR-4100 spectrometer using $\mathrm{KBr}$ pellets in the range of 4000-400 $\mathrm{cm}^{-1} .{ }^{1} \mathrm{H}-\mathrm{NMR}$ spectra of the ligand was measured in $\mathrm{CDCl}_{3}$ using TMS as an internal standard. The TG/DT analysis was recorded on Perkin Elmer TA/SDT-2960 with heating rate $10{ }^{\circ} \mathrm{C} / \mathrm{min}$. XRD was recorded on Philips 3701 employing $\mathrm{CuK}_{\alpha}$. radiation $\left(\lambda=1.541 \AA\right.$ ) in the range $20^{\circ}$ to $90^{\circ}$. The $\mathrm{UV}-\mathrm{V}$ is spectra of the complexes were recorded on Jasco UV-530 Spectrophotometer. Magnetic susceptibility measurements were carried out on Guoy balance at room temperature using $\mathrm{Hg}\left[\mathrm{Co}(\mathrm{SCN})_{4}\right]$ as a calibrant. Conductance was measured on Elico CM-180 conductometer using $1 \mathrm{mM}$ solution in dimethyl sulphoxide.

\section{Synthesis of ligand}

Step-I. For the synthesis of ligand, $50 \mathrm{~mL}$ ethanolic solution of $0.001 \mathrm{~mol}(0.152 \mathrm{~g}$.) of methyl salicylate was taken in round bottomed flask and to this $0.001 \mathrm{~mol}(0.050 \mathrm{~g}$.) of hydrazine in ethanol was added slowly under stirring. The resulting mixture was refluxed for about 3-4 h. It was naturally cooled to room temperature [19]. After cooling, the solid residue was washed with hot ethanol and used for further study (yield 80\%).

Step-II. Above synthesised intermediate $0.001 \mathrm{~mol}$ was refluxed with $0.001 \mathrm{~mol}$ of benzaldehyde in super dry ethanol for $4 \mathrm{~h}$. The precipitate thus formed was filtered, dried in vacuum in presence of $\mathrm{CaCl}_{2}$ and recrystallised in ethanol (yield 72\%) (Figure 2).

\section{Preparation of complexes}

To a hot solution of ligand $(0.02 \mathrm{~mol})$ in chloroform $(25 \mathrm{~mL})$, methanolic solution of metal chloride $(0.01 \mathrm{~mol})$ was added under constant stirring. The $\mathrm{pH}$ of the reaction mixture was adjusted to $7.5-8.5$ by adding $10 \%$ ethanolic ammonia solution and refluxed for about $5 \mathrm{~h}$. The precipitated solid metal complex was filtered and washed with hot methanol, followed by petroleum ether, ethyl acetate and dried over $\mathrm{CaCl}_{2}$ in vacuum desiccator (yield $65 \%$ ). 
Antimicrobial activity

The organisms used were Staphylococcus aureus and Escherichia coli as bacteria for testing antibacterial activity and Aspergillus niger and Trichoderma to test the fungicidal activity of ligand and its complexes.
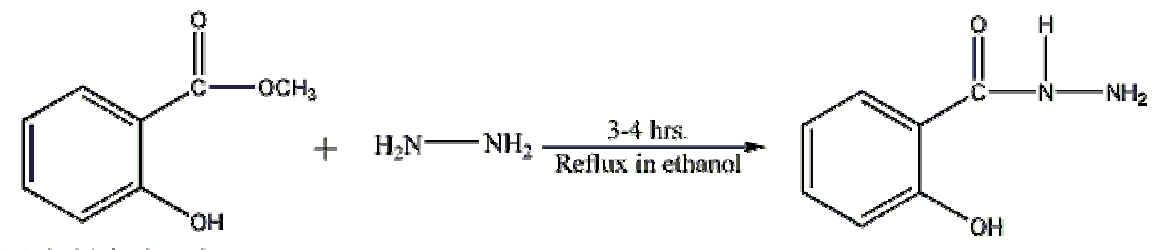

Methyl 2-hydroxybenzoate

2-hydroxybenzohydrazide
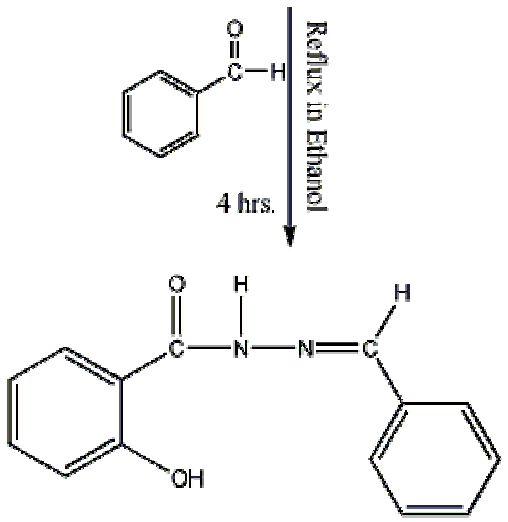

Figure 2. Synthesis of ligand.

N'-benzylidenebenzohydrazide

\section{Antibacterial assay}

The overnight cultures $(0.2 \mathrm{~mL})$ of each bacterium was dispensed into $20 \mathrm{~mL}$ sterile nutrient broth and incubated for about 3-5 $\mathrm{h}$ to standardize the culture. A loopful of the standard cultures was used for the antibacterial assay.

Muller Hilton agar was prepared and $20 \mathrm{~mL}$ of sterilized media was poured in petriplates and allowed for solidification. The bacterial lawn culture was made using sterile cotton swab and labelled. The wells were made with the help of a metallic borer with centers at least $24 \mathrm{~mm}$. Recommended concentration $50 \mu \mathrm{L}$ of the test sample $\left(100 \mathrm{mg} \mathrm{mL}^{-1}\right)$ in water was introduced in the respective wells. Other wells supplemented with reference antibacterial drug. The plates were incubated immediately at $37^{\circ} \mathrm{C}$ for 24 hours. Activity was determined by measuring the diameter of zones showing complete inhibition $(\mathrm{mm})$. Growth inhibition was compared with known antibiotics viz. ciprofloxacin.

\section{Antifungal assay}

The glucose-nitrate (GN) medium required for the growth of fungi was prepared by dissolving $10 \mathrm{~g}$ of glucose, $2.5 \mathrm{~g}$ of $\mathrm{KNO}_{3}, 1 \mathrm{~g}$ of $\mathrm{KH}_{2} \mathrm{PO}_{4}$ and $0.5 \mathrm{~g}$ of $\mathrm{MgSO}_{4} \cdot 7 \mathrm{H}_{2} \mathrm{O}$ in one liter of sterile distilled water. The glucose and $\mathrm{KNO}_{3}$ in the medium are the sources of carbohydrate and nitrogen, respectively, while $\mathrm{KH}_{2} \mathrm{PO}_{4}$ and $\mathrm{MgSO}_{4} \cdot 7 \mathrm{H}_{2} \mathrm{O}$ are the activators for growth. 
The cultures of the fungi were purified by single spore isolation technique. The glucosenitrate medium was used for the growth of fungi. The mycelial biomass was then dried along with filter paper in an oven maintained at $65 \pm 5{ }^{0} \mathrm{C}$ to constant weight, cooled and finally weighed on semi micro analytical balance. The mycelial dry weight (MDW) was obtained by subtracting the weight of mycelium free filter paper from final dry weight. Three replicates of each treatment were repeated in all experiments. The MDW was corrected each time by subtracting the dry weight obtained from incubated flask under similar experimental conditions. The percent decrease in mycelia dry weight due to the test compound in each case was calculated and tabulated in terms of average percentage inhibition.

\section{RESULTS AND DISCUSSION}

All the complexes are coloured solids, air stable and are having line solubility in polar solvents DMF and DMSO. The elemental analysis showed 1:2 (metal: ligand) stoichiometry for all the complexes. Micro analytical data and molar conductance values are given in Table 1 . The metal contents in complexes were estimated by gravimetric analysis [20]. All the complexes show low conductance which indicates their non-electrolytic nature. The magnetic measurement studies suggest that the $\mathrm{Cu}$ (II), $\mathrm{Co}(\mathrm{II}), \mathrm{Mn}$ (II) and $\mathrm{Ce}(\mathrm{III})$ complexes exhibit paramagnetic whereas the $\mathrm{La}(\mathrm{III})$ show diamagnetic behavior.

Table 1. Physical characterization, analytical and molar conductance data of compounds.

\begin{tabular}{|c|c|c|c|c|c|c|c|c|}
\hline Compound & F.W. & $\begin{array}{c}\text { M.P. } \\
\text { decom. } \\
\text { Temp }{ }^{\circ} \mathrm{C}\end{array}$ & Colour & 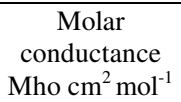 & $\begin{array}{c}\% \mathrm{C} \\
\text { (calcd.) }\end{array}$ & $\begin{array}{c}\% \mathrm{H} \\
\text { (calcd.) }\end{array}$ & $\begin{array}{c}\% \mathrm{~N} \\
\text { (calcd.) }\end{array}$ & $\begin{array}{c}\% \mathrm{M} \\
\text { (calcd.) }\end{array}$ \\
\hline $\mathrm{H}_{2} \mathrm{~L}$ & 240 & 142 & White & & $\begin{array}{c}70.10 \\
(70.28)\end{array}$ & $\begin{array}{c}4.45 \\
(4.63)\end{array}$ & $\begin{array}{c}11.55 \\
(11.70)\end{array}$ & \\
\hline$[\mathrm{CuL}]$ & 543 & 252 & $\begin{array}{l}\text { Pale } \\
\text { green }\end{array}$ & 10.12 & $\begin{array}{c}62.00 \\
(62.04)\end{array}$ & $\begin{array}{c}3.90 \\
(4.09)\end{array}$ & $\begin{array}{c}10.10 \\
(10.33)\end{array}$ & $\begin{array}{c}11.60 \\
(11.72)\end{array}$ \\
\hline [CoL] & 574 & 260 & Orange & 12.00 & $\begin{array}{c}58.55 \\
(58.64)\end{array}$ & $\begin{array}{c}4.45 \\
(4.57)\end{array}$ & $\begin{array}{c}9.60 \\
(9.77)\end{array}$ & $\begin{array}{c}10.10 \\
(10.27\end{array}$ \\
\hline$[\mathrm{MnL}]$ & 570 & 292 & Yellow & 10.10 & $\begin{array}{c}58.95 \\
(59.05)\end{array}$ & $\begin{array}{c}4.50 \\
(4.60)\end{array}$ & $\begin{array}{c}9.70 \\
(9.83)\end{array}$ & $\begin{array}{c}9.55 \\
(9.64)\end{array}$ \\
\hline [LaL] & 654 & $>300$ & Pale yellow & 25.00 & $\begin{array}{c}51.35 \\
(51.46) \\
\end{array}$ & $\begin{array}{c}3.90 \\
(4.01)\end{array}$ & $\begin{array}{c}8.45 \\
(8.57) \\
\end{array}$ & $\begin{array}{r}21.10 \\
(21.25) \\
\end{array}$ \\
\hline [CeL] & 655 & $>300$ & Brick red & 27.00 & $\begin{array}{c}51.22 \\
(51.37)\end{array}$ & $\begin{array}{c}3.93 \\
(4.00)\end{array}$ & $\begin{array}{c}8.42 \\
(8.55)\end{array}$ & $\begin{array}{c}21.30 \\
(21.40)\end{array}$ \\
\hline
\end{tabular}

${ }^{1} H$-NMR spectra

${ }^{1} \mathrm{H}-\mathrm{NMR}$ spectra of synthesised ligand was recorded in $\mathrm{CDCl}_{3}$. It shows following signals at 4.8 $\delta(\mathrm{s}, 1 \mathrm{H},-\mathrm{C}-\mathrm{N}-\mathrm{H}), 7.08 \delta(\mathrm{dd}, 2 \mathrm{H}, \mathrm{Ar}-\mathrm{H}), 7.22 \delta(\mathrm{dd}, 3 \mathrm{H}, \mathrm{Ar}-\mathrm{H}), 7.43 \delta(\mathrm{s}, 3 \mathrm{H}, \mathrm{Ar}-\mathrm{H}), 7.55 \delta$ (dd, $2 \mathrm{H}, \mathrm{Ar}-\mathrm{H}), 7.85 \delta(\mathrm{s}, 1 \mathrm{H}, \mathrm{N}=\mathrm{C}-\mathrm{H})$, and $10.23 \delta$ (s, $1 \mathrm{H}, \mathrm{Ar}-\mathrm{OH})$.

Mass spectra of the ligand

Mass spectral data of the ligand $\mathrm{H}_{2} \mathrm{~L}$ has been recorded and shows the molecular ion peak $\left(\mathrm{M}^{+}\right)$ at $\mathrm{m} / \mathrm{z}=241.1$ as indicated by the peaks corresponding to their molecular masses.

IR spectra

The FT-IR spectrum of the free ligand shows four characteristic bands at 3260-3300, 3450, 1655 and $1610 \mathrm{~cm}^{-1}$ assignable to $(-\mathrm{N}-\mathrm{H})$, free (-O-H) stretching phenolic moiety, amide 
carbonyl $(-\mathrm{C}=\mathrm{O})$ and azomethine $(-\mathrm{C}=\mathrm{N})$, stretching modes, respectively. The absence of a weak broad band in 3260-3300 $\mathrm{cm}^{-1}$ region, noted in the spectra of the metal complexes indicates deprotonation of bonded (-NH) group during the complexation and subsequent coordination of the oxygen of amide carbonyl to metal ion [21]. The $v(C=N)$ band is shifted to lower wavenumber with respect to free ligand, indicating that the nitrogen of the azomethine group is coordinated to the metal ion, which was further confirmed by observation of the red shift in the $v(\mathrm{~N}-\mathrm{N})$ stretching frequency from $923 \mathrm{~cm}^{-1}$ to $953 \mathrm{~cm}^{-1}$ regions [22-24]. New bands observed in the complexes at 1621 and $1625 \mathrm{~cm}^{-1}$ are attributed to the $>\mathrm{C}=\mathrm{N}-\mathrm{N}=\mathrm{C}<$ group [25]. The spectra of metal chelates showed new bands in the 457-540 and 407-478 $\mathrm{cm}^{-1}$ regions which can be assigned to $v(\mathrm{M}-\mathrm{O})$ and $(\mathrm{M}-\mathrm{N})$ vibrations, respectively [23]. The spectra of $\mathrm{Co}(\mathrm{II}), \mathrm{Mn}(\mathrm{II})$, $\mathrm{La}$ (III) and Ce(III) showed a strong band at $3150-3600 \mathrm{~cm}^{-1}$ region, suggesting the presence of coordinated water in these metal complexes [20] The presence of coordinated water is further confirmed by the appearance of non-ligand band in $830-840 \mathrm{~cm}^{-1}$ region [26]. The presence of coordinated water is also established and supported by TG/DT analysis of these complexes. Hence co-ordination takes place via oxygen of amide and nitrogen of azomethine group of ligand molecule.

\section{Electronic absorption spectra and magnetic measurements}

Magnetic and electronic absorption spectral data of the compounds are given in Table 2. The electronic spectra of $\mathrm{Cu}(\mathrm{II})$ complex in DMSO show bands at 10150, 13690, $29250 \mathrm{~cm}^{-1}$ assignable to a ${ }^{2} \mathrm{~B}_{1 \mathrm{~g}} \rightarrow{ }^{2} \mathrm{~A}_{1 \mathrm{~g}}$ transition and charge transfer, respectively. The electronic spectral data coupled with observed magnetic moment 1.8 B.M. suggest square planar geometry for $\mathrm{Cu}$ (II) complex [28, 29]. Co(II) complex exhibits three bands at 12235, 16019 and $27833 \mathrm{~cm}^{-1}$ assignable to ${ }^{4} \mathrm{~T}_{1 \mathrm{~g}} \rightarrow \mathrm{T}_{2 \mathrm{~g}}(\mathrm{~F}),{ }^{4} \mathrm{~T}_{1 \mathrm{~g}} \rightarrow{ }^{4} \mathrm{~A}_{2 \mathrm{~g}}(\mathrm{~F})$ transitions and charge transfer, respectively. These transitions and observed magnetic moment 4.8 B.M. indicate high spin octahedral geometry of the complex [29, 30]. In case of Mn(II) complex, the observed magnetic moment 5.7 B.M. and the spectral bands at 16511,24290 and $27881 \mathrm{~cm}^{-1}$ assignable to ${ }^{6} \mathrm{~A}_{1 \mathrm{~g}} \rightarrow{ }^{4} \mathrm{~T}_{1 \mathrm{~g}},{ }^{6} \mathrm{~A}_{1 \mathrm{~g}} \rightarrow{ }^{4} \mathrm{~T}_{2 \mathrm{~g}}$ and charge transfer respectively, indicate octahedral geometry for the Mn(II) complex [28, 31]. The calculated values of ligand field splitting energy $(10 \mathrm{Dq})$, Racah interelectronic repulsion parameter (B), covalent factor $(\beta)$, ratio $v_{2} / v_{1}$ and ligand field stabilization energy (LFSE) (Table 3 ) support the proposed geometry for all the as-synthesised metal complexes. Where as La(III) and $\mathrm{Ce}(\mathrm{III})$ complexes has no significant absorption in the visible region [32].

Table 2. Magnetic and electronic absorption spectral data of compounds.

\begin{tabular}{|c|c|c|c|c|}
\hline Compound & $\begin{array}{c}\text { Magnetic moment } \\
\mu_{\text {eff }} \text { (B.M.) }\end{array}$ & $\begin{array}{l}\text { Frequency in } \mathrm{cm}^{-1} \\
\left(\varepsilon \text { in } \mathrm{Lmol}^{-1} \mathrm{~cm}^{-1}\right)\end{array}$ & Band Assignment & Geometry \\
\hline $\begin{array}{l}{\left[\mathrm{C}_{14} \mathrm{H}_{11} \mathrm{~N}_{2} \mathrm{O}_{2}\right]} \\
\mathrm{H}_{2} \mathrm{~L}\end{array}$ & - & $\begin{array}{l}32794(220) \\
33798(900) \\
34146(957)\end{array}$ & $\begin{array}{c}\text { INCT }^{\mathrm{a}} \\
\text { INCT } \\
\mathrm{dxy} \rightarrow \mathrm{dx}^{2}-\mathrm{y}^{2}\end{array}$ & \\
\hline$\left[\mathrm{C}_{28} \mathrm{H}_{22} \mathrm{~N}_{4} \mathrm{O}_{4} \mathrm{Cu}\right]$ & 1.8 & $\begin{array}{c}10150(27) \\
13690(10) \\
29250(273)\end{array}$ & $\begin{array}{c}{ }^{2} \mathrm{~B}_{1 \mathrm{~g}} \rightarrow{ }^{2} \mathrm{~A}_{1 g} \\
\text { IN C T } \\
\text { IN C T }\end{array}$ & Square planar \\
\hline$\left[\mathrm{C}_{28} \mathrm{H}_{26} \mathrm{~N}_{4} \mathrm{O}_{6} \mathrm{Co}\right]$ & 4.8 & $\begin{array}{l}12235(146) \\
16019(858) \\
27833(880)\end{array}$ & $\begin{array}{c}{ }^{4} \mathrm{~T}_{1 \mathrm{~g}} \rightarrow \mathrm{T}_{2 \mathrm{~g}}(\mathrm{~F}) \\
{ }^{4} \mathrm{~T}_{1 \mathrm{~g}} \rightarrow{ }^{4} \mathrm{~A}_{2 \mathrm{~g}}(\mathrm{~F}) \\
\text { I N C T }\end{array}$ & Octahedral \\
\hline$\left[\mathrm{C}_{28} \mathrm{H}_{26} \mathrm{~N}_{4} \mathrm{O}_{6} \mathrm{Mn}\right]$ & 5.7 & $\begin{array}{c}16511(7) \\
24290(187) \\
27881(205)\end{array}$ & $\begin{array}{c}{ }^{6} \mathrm{~A}_{1 g} \rightarrow{ }^{4} \mathrm{~T}_{1 g} \\
{ }^{6} \mathrm{~A}_{1 \mathrm{~g}} \rightarrow{ }^{4} \mathrm{~T}_{2 \mathrm{~g}} \\
\text { I N C T }\end{array}$ & Octahedral \\
\hline
\end{tabular}


Table 3. Ligand field parameter of metal complexes.

\begin{tabular}{|l|c|c|c|c|c|c|}
\hline Compound & $\begin{array}{c}\text { Ligand field } \\
\text { splitting energy } \\
\text { Dq cm }\end{array}$ & $\begin{array}{c}\text { Racha electronic } \\
\text { repulsion parameter } \\
\mathrm{B} \mathrm{cm}^{-1}\end{array}$ & $\begin{array}{c}\text { Covalent } \\
\text { factor }(\beta)\end{array}$ & $\begin{array}{c}\% \beta \\
v_{2} / v_{1}\end{array}$ & $\begin{array}{c}\text { Ligand field } \\
\text { stabilization } \\
\text { energy }\left(\mathrm{kcal}_{\mathrm{mol}}{ }^{-1}\right)\end{array}$ \\
\hline $\mathrm{CuL}_{2}$ & 1015 & 124 & - & & 1.348 & 28.927 \\
\hline $\mathrm{CoL}_{2}$ & 1223 & 476 & 0.4906 & 50.93 & 1.309 & 34.869 \\
\hline $\mathrm{MnL}_{2}$ & 1651 & 175 & 0.1830 & 81.69 & 1.471 & 47.056 \\
\hline
\end{tabular}

\section{$X$-ray diffraction study}

The X-ray diffractogram of a representative metal complex of Co(II) was scanned in the range $5-100^{\circ}$ at wavelength $1.54 \AA$ (Figure 3 ). The diffractogram and associated data depict $2 \theta$ values for each peak, relative intensity and inter planar spacing (d-values). The diffractogram of $\mathrm{Co}$ (II) complex showed twelve reflections with maxima at $2 \theta\left(30.49^{\circ}\right)$ corresponding to $d$ value 2.9292 $\AA$. The X-ray diffraction pattern of the complex with respect to major peaks having relative intensity greater than $10 \%$ have been indexed by using computer programme [30]. The above indexing method also yields Miller indices (hkl), unit cell parameters and volume. The unit cell of Co(II) complex yielded values of lattice constants, $a=8.34 \AA$, b = 3.16 $⿱$, c $=6.75 \AA$ and unit cell volume, $\mathrm{V}=165.39(\AA)^{3}$. In concurrence with these cell parameters of Co(II) complex, the condition such as $\mathrm{a} \neq \mathrm{b} \neq \mathrm{c}$ and $\alpha=\gamma=90^{\circ} \neq \beta$ required for the compounds to be monoclinic were tested and found to be satisfactory. The above values indicate that the metal complex has monoclinic crystal system. Experimental density value of the complex was determined by using specific gravity method [33] and found to be $2.32 \mathrm{~g} \mathrm{~cm}^{-3}$ for Co(II) complex on the basis of these studies, theoretical density were computed and found to be $2.33 \mathrm{~g} \mathrm{~cm}^{-3}$ for Co(II) complex. Comparison of experimental and theoretical density shows good agreement within the limits of experimental error.

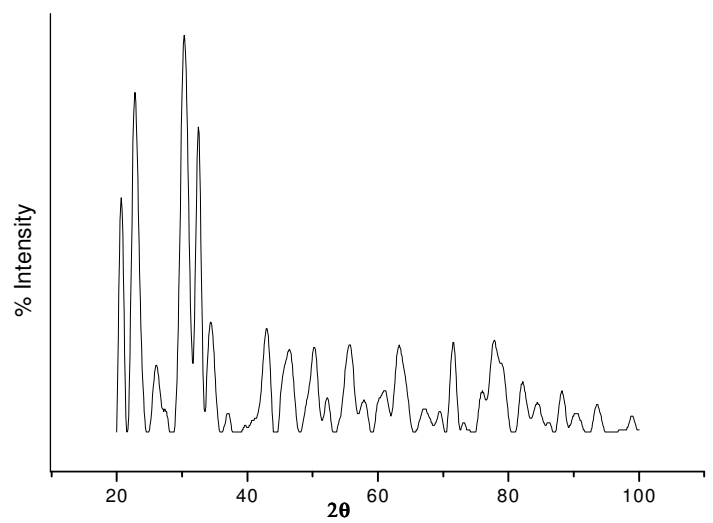

Figure 3. X-ray diffractogram of Co(II) complex.

\section{Thermal analysis}

The simultaneous TG/DT analysis of a representative metal complex of $\mathrm{Cu}$ (II) was studied from ambient temperature to $1000{ }^{\circ} \mathrm{C}$ in nitrogen atmosphere using $\alpha-\mathrm{Al}_{2} \mathrm{O}_{3}$ as reference. The thermogram curve of $\mathrm{Cu}$ (II) complex shows no mass loss up to $250{ }^{\circ} \mathrm{C}$ indicating absence of coordinated water molecule [20]. In the TG curve of $\mathrm{Cu}$ (II) complex, the first step of 
decomposition from $260{ }^{\circ} \mathrm{C}$ to $400{ }^{\circ} \mathrm{C}$ show mass loss $23.20 \%$ (calcd. $22.50 \%$ ), an exothermic peak $\Delta \mathrm{T}_{\max }=353{ }^{\circ} \mathrm{C}$, in DTA may be attributed to the decomposition of non coordinated part of ligand. The second slow step from 410 to $905^{\circ} \mathrm{C}$, with mass loss of $58.75 \%$ (calcd. 57.50\%) corresponds to decomposition of coordinated part of ligand. A broad endotherm in DTA is observed for this. The mass of final residue corresponds to stable $\mathrm{CuO}, 18.01 \%$ (calcd. 17.20 $\%)$.

\section{Kinetic calculations}

The kinetic and thermodynamic parameters viz order of reaction (n), energy of activation $\left(\mathrm{E}_{\mathrm{a}}\right)$, pre-exponential factor $(\mathrm{z})$, entropy of activation $(\Delta S)$ and free energy change $(\Delta \mathrm{G})$ together with correlation coefficient ( $r$ ) for non-isothermal decomposition of metal complexes have been determined by Horowitz-Metzer (HM) approximation method and Coats-Redfern integral method [33, 34].

Horowitz-Metzer (HM) approximation method

$$
\log \left(\frac{1-(1-\alpha)^{1-n}}{(1-n)}\right)=\frac{E_{a} \theta}{2.303 R T_{s}^{2}}+\log \frac{Z R T_{s}^{2}}{E \beta}-\frac{E}{2.303 R T_{s}^{2}}
$$

where $\alpha=$ fraction decomposed, $\beta=$ heating rate $\left(10{ }^{\circ} \mathrm{C} / \mathrm{min}\right), \mathrm{n}=$ order of reaction, $\mathrm{R}=$ molar gas constant, $\mathrm{T}_{\mathrm{s}}=$ temperature at half wt. Loss, $\mathrm{k}=$ Boltzman constant, $\mathrm{Z}=$ frequency factor, $\mathrm{h}=$ Planck's constant.

The equation used for calculating entropy change $(\Delta \mathrm{S})$ is given below.

$$
\Delta S=2.303 R \log \frac{Z h}{k T_{s}}
$$

where, $\mathrm{k}=$ Boltzman constant, $\mathrm{h}=$ Planck's constant, $\beta=$ rate of heating $10{ }^{0} \mathrm{C} / \mathrm{min}$., $\mathrm{R}$ - molar gas constant and $\mathrm{T}_{\mathrm{s}}=$ peak temperature.

\section{Coats Redfern method}

The thermodynamic activation parameters of decomposition processes of complexes were calculated by this method. The activation energy $\left(\mathrm{E}_{\mathrm{a}}\right)$, enthalpy $\left(\Delta \mathrm{H}^{*}\right)$, entropy $(\Delta \mathrm{S})$ and Gibbs free energy change of the decomposition $\left(\Delta \mathrm{G}^{*}\right)$ were evaluated by employing the Coats Redfern relation

$$
\log \left[\frac{\log \left\{W_{f} / W_{f}-W\right\}}{T^{2}}=\log \left[\frac{Z R}{\theta E^{*}}\left(1-\frac{2 R T}{E^{*}}\right)\right]-\frac{E^{*}}{2.303 R T}\right.
$$

where $\mathrm{W}_{\mathrm{f}}$ is the mass loss at the completion of the reaction, $\mathrm{W}$ is the mass loss up to temperature $T, R$ is gas constant, $E^{*}$ is activation energy in $\mathrm{kJ} / \mathrm{mol}, \theta$ is the heating rate $\left(1-\left(2 \mathrm{RT} / \mathrm{E}^{*}\right) \cong 1\right.$. A plot of L.H.S. of equation against $1 / \mathrm{T}$ gave a slope from which $\mathrm{E}^{*}$ was calculated:

$$
\begin{aligned}
\Delta H^{*} & =E^{*}-R T \\
\Delta S^{*} & =2.303 R\left[\left(\log \frac{Z h}{K T}\right)\right] \\
\Delta G^{*} & =\Delta H^{*}-T \Delta S^{*}
\end{aligned}
$$


The data is given in Table 4. The results show that the value obtained by two methods is comparable. The calculated value of energy of activation of the $\mathrm{Cu}$ (II) complex is relatively low indicating the autocatalytic effect of metal ion on thermal decomposition of the metal complex $[35,36]$. The negative value of entropy of activation indicates that the activated complex is more ordered than the reactant and that the reaction is slow. The more ordered nature may be due to the polarization of bonds in activated state which might happen through charge transfer electronic transition.

Table 4. The kinetic parameter of metal complexes calculated by the methods Horowitz-Metzger (HM) and Coats-Redfern (CR).

\begin{tabular}{|c|c|c|c|c|c|c|c|c|}
\hline Complex & Step & $\mathrm{n}$ & Method & \begin{tabular}{|c|c|}
$\begin{array}{c}\mathrm{E}_{\mathrm{a}} \\
\left(\mathrm{kJmol}^{-1)}\right.\end{array}$ \\
\end{tabular} & $\begin{array}{c}\mathrm{Z} \\
\mathrm{S}^{-1} \\
\end{array}$ & $\begin{array}{c}\Delta \mathrm{S} \# \\
\mathrm{JK}^{-1} \mathrm{~mol}^{-1} \\
\end{array}$ & $\begin{array}{c}\Delta \mathrm{G} \# \\
\left(\mathrm{kJmol}^{-1}\right)\end{array}$ & $\begin{array}{c}\text { Corelation } \\
\text { coefficient }(\mathrm{r})\end{array}$ \\
\hline \multirow{4}{*}{$\mathrm{Cu}$ (II) } & \multirow[b]{2}{*}{ I } & \multirow{2}{*}{1.4} & HM & 46.80 & $2.6 \times 10^{4}$ & -179 & 57.12 & 0.9878 \\
\hline & & & $\mathrm{CR}$ & 39.84 & $5.2 \times 10^{3}$ & -215 & 52.40 & 0.9964 \\
\hline & \multirow[t]{2}{*}{ II } & \multirow{2}{*}{1.2} & HM & 40.76 & $4.8 \times 10^{4}$ & -247 & 62.69 & 0.9922 \\
\hline & & & $\mathrm{CR}$ & 18.56 & $4.7 \times 10^{4}$ & -274 & 59.87 & 0.9986 \\
\hline
\end{tabular}

Antimicrobial activity

The antimicrobial activity of ligand and its metal complexes were tested in vitro against bacteria such as Staphylococcus aureus and Escherichia coli by paper disc plate method [37]. The compounds were tested at the concentration 500 and $1000 \mu \mathrm{g} / \mathrm{mL}$ in DMF and compared with known antibiotics viz ciproflaxin (Table 5). For fungicidal activity, compounds were screened in vitro against Aspergillus Niger and Trichoderma by mycelia dry weight method [38] with glucose nitrate media. The compounds were tested at the concentration 250 and $500 \mu \mathrm{g} / \mathrm{mL}$ in DMF and compared with control (Table 6). From Table 5 and 6 , it is clear that the inhibition by metal chelates is higher than that of a ligand and metal salts. The results are in good agreement with previous findings with respect to comparative activity of free ligand and its complexes [37, 38]. The metal chelates have higher antibacterial activity than the corresponding free ligand and control against the same microorganism under identical experimental conditions. Such enhanced activity of metal chelates is due to increased lipophilic nature of the metal ions in complexes [39]. The increase in activity with concentration is due to the effect of metal ions on the normal process.

In case of antibacterial studies it was observed that, the ligand is moderately active towards Stapylococcus and less active towards E. coli. Comparison of activities of the ligand and its metal chelates showed that the copper complex is approximately found to be two times more active as the ligand, against E. coli and activity of ligand against Stapylococcus is found to be increased after chelation. $\mathrm{Cu}(\mathrm{II})$ complex show two times more activity than other metal complexes. The cobalt and manganese complexes show the activity comparable to copper complex. However lanthanum and cerium complexes show less activity against E. coli and Stapylococcus. The activity of these complexes follow the order $\mathrm{Cu}>\mathrm{Co}>\mathrm{Mn}>\mathrm{La}>\mathrm{Ce}$. This high antibacterial activity of ligand and its metal complexes can be attributed on the basis of Overtone's concepts and Tweedy's concept. According to these concepts, chelation tends to make a liquid more potential bacterial agent. The increased activity depends upon chelation is attributed to the positive charge of the metal partially shaired with donor atom present on the Ligand and possible $\pi$-electron delocalization over the whole chelatering. This, in turn, increases the lipophilic character of the metal chelate. And favours its permeation through the lipid layer of the bacterial membranes. Inhibition was found to increase with increasing the concentration of metal complex.

Investigation of antifungal activity of the ligand and its metal complexes revealed that all metal chelates are more fungi toxic than their parent ligand (Table 6). The antifungal activity of

Bull. Chem. Soc. Ethiop. 2011, 25(3) 
the ligand is found to enhance several times on being coordinated with metal ions. The activity of these complexes follow the order $\mathrm{Cu}>\mathrm{Co}>\mathrm{Mn}>\mathrm{La}>\mathrm{Ce}$. Comparison of the activities of ligand and its metal chelates shows that the copper complex is approximately two times more active as ligand against Aspergillus niger. Activity of ligand against Trichoderma also increases after chelation with $\mathrm{Cu}(\mathrm{II}), \mathrm{Co}(\mathrm{II}), \mathrm{Mn}(\mathrm{II}), \mathrm{La}(\mathrm{III})$ and $\mathrm{Ce}(\mathrm{III})$.

As a result, metal complexes of $\mathrm{Cu}$ (II), $\mathrm{Co}$ (II) and $\mathrm{Mn}$ (II) show good antibacterial and antifungal activity, where as $\mathrm{La}(\mathrm{III})$ and $\mathrm{Ce}(\mathrm{III})$ complexes shows comparatively less activity.

Table 5. Antibacterial activity of ligand and its metal complexes.

\begin{tabular}{|l|c|c|c|c|}
\hline \multirow{2}{*}{ Test Compound } & \multicolumn{4}{|c|}{ Inhibition zone $(\mathrm{mm})$} \\
\cline { 2 - 5 } & \multicolumn{2}{|c|}{ E. coli } & \multicolumn{2}{c|}{ Staphylococcus } \\
\cline { 2 - 5 } & $500(\mu \mathrm{g} / \mathrm{mL})$ & $1000(\mu \mathrm{g} / \mathrm{mL})$ & $500(\mu \mathrm{g} / \mathrm{mL})$ & $1000(\mu \mathrm{g} / \mathrm{mL})$ \\
\hline Ciproflaxin & 29 & 32 & 31 & 35 \\
\hline$\left[\mathrm{C}_{14} \mathrm{H}_{11} \mathrm{~N}_{2} \mathrm{O}_{2}\right]\left(\mathrm{H}_{2} \mathrm{~L}\right)$ & 11 & 14 & 11 & 16 \\
\hline$\left[\mathrm{C}_{28} \mathrm{H}_{22} \mathrm{~N}_{4} \mathrm{O}_{4} \mathrm{Cu}\right]$ & 14 & 24 & 15 & 26 \\
\hline$\left[\mathrm{C}_{28} \mathrm{H}_{26} \mathrm{~N}_{4} \mathrm{O}_{6} \mathrm{Co}\right]$ & 13 & 20 & 12 & 18 \\
\hline$\left[\mathrm{C}_{28} \mathrm{H}_{26} \mathrm{~N}_{4} \mathrm{O}_{6} \mathrm{Mn}\right]$ & 13 & 21 & 14 & 19 \\
\hline$\left[\mathrm{C}_{28} \mathrm{H}_{26} \mathrm{~N}_{4} \mathrm{O}_{6} \mathrm{La}\right]$ & 12 & 16 & 12 & 17 \\
\hline$\left[\mathrm{C}_{28} \mathrm{H}_{26} \mathrm{~N}_{4} \mathrm{O}_{6} \mathrm{Ce}\right]$ & 12 & 17 & 12 & 18 \\
\hline
\end{tabular}

Table 6. Antifungal activity of compounds yield of mycelial dry weight in $\mathrm{mg}$ (\% inhibition)

\begin{tabular}{|l|c|c|c|c|}
\hline \multirow{2}{*}{ Test compound } & \multicolumn{2}{|c|}{ Aspergillus niger } & \multicolumn{2}{c|}{ Trichoderma } \\
\cline { 2 - 5 } & $250(\mu \mathrm{g} / \mathrm{mL})$ & $500(\mu \mathrm{g} / \mathrm{mL})$ & $250(\mu \mathrm{g} / \mathrm{mL})$ & $500(\mu \mathrm{g} / \mathrm{mL})$ \\
\hline Control & 79 & 79 & 70 & 70 \\
\hline$\left[\mathrm{C}_{14} \mathrm{H}_{11} \mathrm{~N}_{2} \mathrm{O}_{2}\right]\left(\mathrm{H}_{2} \mathrm{~L}\right)$ & $58(27)$ & $25(69)$ & $38(46)$ & $17(76)$ \\
\hline$\left[\mathrm{C}_{28} \mathrm{H}_{22} \mathrm{~N}_{4} \mathrm{O}_{4} \mathrm{Cu}\right]$ & $58(52)$ & $12(85)$ & $18(75)$ & $05(93)$ \\
\hline$\left[\mathrm{C}_{28} \mathrm{H}_{26} \mathrm{~N}_{4} \mathrm{O}_{6} \mathrm{Co}\right]$ & $41(46)$ & $12(85)$ & $30(58)$ & $06(92)$ \\
\hline$\left[\mathrm{C}_{28} \mathrm{H}_{26} \mathrm{~N}_{4} \mathrm{O}_{6} \mathrm{Mn}\right]$ & $42(47)$ & $14(84)$ & $32(55)$ & $08(89)$ \\
\hline$\left[\mathrm{C}_{28} \mathrm{H}_{26} \mathrm{~N}_{4} \mathrm{O}_{6} \mathrm{La}\right]$ & $45(44)$ & $17(79)$ & $40(43)$ & $12(83)$ \\
\hline$\left[\mathrm{C}_{28} \mathrm{H}_{26} \mathrm{~N}_{4} \mathrm{O}_{6} \mathrm{Ce}\right]$ & $47(41)$ & $19(76)$ & $43(39)$ & $15(79)$ \\
\hline
\end{tabular}

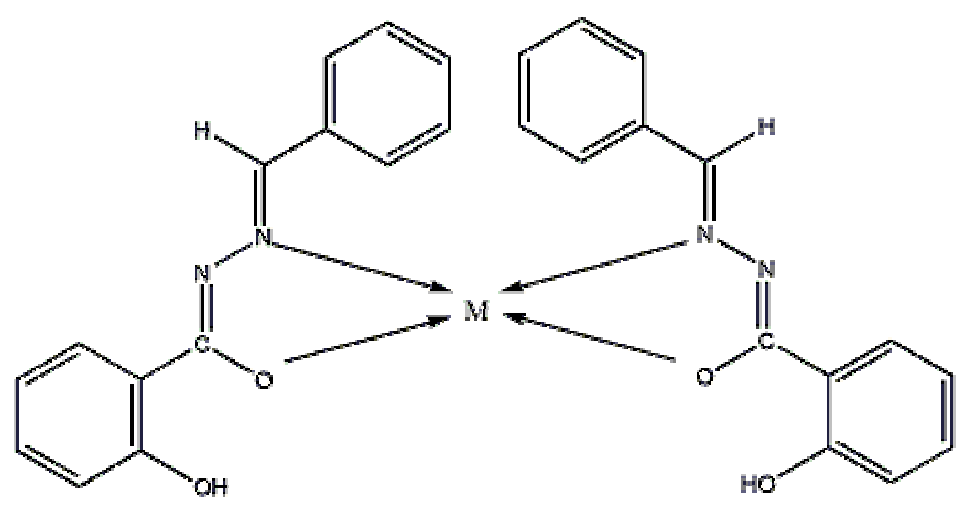

(a) 


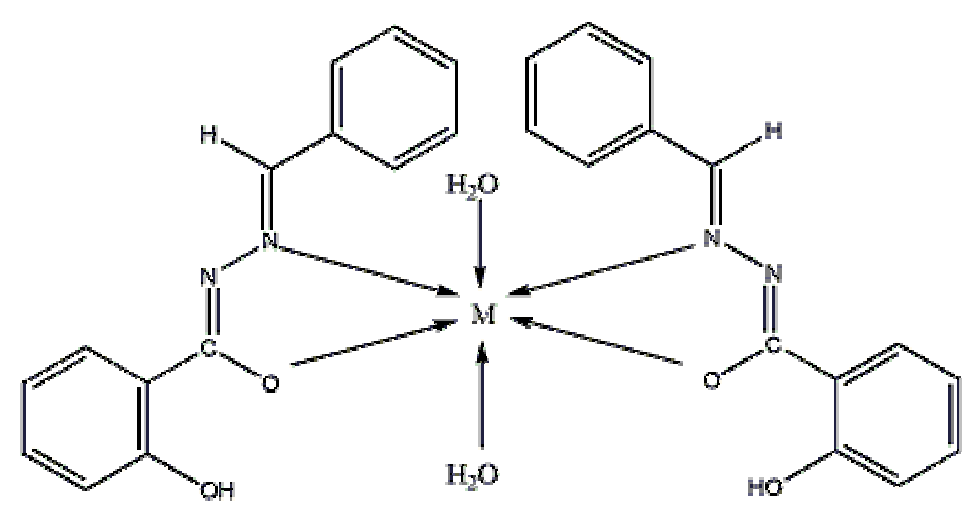

(b)

Figure 4. The proposed structure of the complexes. a) when $\mathrm{M}=\mathrm{Cu}(\mathrm{II})$ and $\mathrm{b}$ ) when $\mathrm{M}=\mathrm{Co}(\mathrm{II})$, $\mathrm{Mn}(\mathrm{II}), \mathrm{La}(\mathrm{III})$ and $\mathrm{Ce}(\mathrm{III})$.

\section{CONCLUSIONS}

In the light of above discussion we have proposed square-planar geometry for $\mathrm{Cu}$ (II) complex and octahedral geometry for $\mathrm{Co}(\mathrm{II}), \mathrm{Mn}$ (II), $\mathrm{La}(\mathrm{III})$ and $\mathrm{Ce}$ (III) complexes. On the basis of the physico-chemical and spectral data discussed above, one can assume that the ligand behave as monobasic, ON bidentate, coordinating via amide oxygen and azomethin nitrogen as illustrated in Figure 4. The complexes are biologically active and are having enhanced antimicrobial activities compared to free ligand. Thermal study reveals thermal stability of metal complexes. The XRD study suggests monoclinic crystal system for Co(II) complex.

\section{ACKNOWLEDGEMENTS}

The authors are grateful to the Head, Department of Chemistry, Dr. Babasaheb Ambedkar Marathwada University, Aurangabad for providing the laboratory facilities.

\section{REFERENCES}

1. Naik, V.M.; Sambrani, M.I.; Mallur, M.B. Indian. J. Chem. 2008, 47, 1793.

2. Narang, K.K.; Singh, V.P. Synth. React. Inorg. Met.-Org. Chem. 1997, $27,721$.

3. Chowdhury, D.A.; Uddin, M.N.; Sarker, M.A.H. Chiang Mai J. Sci. 2008, 35, 483.

4. Clear, M.J. Coord. Chem. Rev. 1974, 12, 349.

5. Ali, M.A.; Tarafdar, M.T.H. J. Inorg. Nucl. Chem. 1977, 39, 1785.

6. Maurya, R.C.; Verma, R.; Singh, T. Synth. React. Inorg. Met.-Org.Chem. 2003, 33, 309.

7. Ali, M.A.; Livingstone, S.E. Coord. Chem. Rev. 1974, 13, 101.

8. Williams, D.R. Chem. Rev. 1972, 72, 203.

9. Loncle, C.; Brunel, J.M.; Vidal, N.; Dherbomez, M.; Letourneux, Y. Eur. J. Med. Chem. 2004, 39, 1067.

10. Kucukguzel, S.G.; Mazi, A.; Sahin, F.; Ozturk, S.; Stables, J.P. Eur. J. Med. Chem. 2003, 38,1005 .

11. Todeschini, R.; de Miranda, A.L.P.; da Silva, K.C.M.; Parrini, S.C., Barreiro, E.J. Eur. J. Med. Chem., 1998, 33, 189. 
Transition and rare earth metal complexes of N-benzylidene-2-hydroxybenzohydrazide 391

12. Melnyk, P.; Leroux, V.; Sergheraert, C.; Grellier, P.; Sergheraert, C. Bioorg. Med. Chem. Lett. 2006, 16, 31.

13. Lima, P.C.; Lima, L.M.; da Silva, K.C.M.; O. Le'da, P.H.; de Miranda, A.L.P.; Fraga, C.A.M.; Barreiro, E.J. Eur. J. Med. Chem. 2000, 35, 187.

14. Cunha, C.; Figueiredo, J.M.; Tributino, J.L.M.; Miranda, A.L.P; Castro, H.C.; Zingali, R.B.; Fraga, C.A.M.; V. de Souza, M.C.B.; Ferreira, V.F.; Barreiro, E.J. Bioorg. Med. Chem. 2003, 11, 2051.

15. Bedia, K.K.; U. Seda, O. Elc.; Fatma, K.; Nathaly, S.; Sevim, R.; Dimoglo, A. Eur. J. Med. Chem. 2006, 41, 1253.

16. Terzioglu, N.; Gu“" rsoy, A. Eur. J. Med. Chem. 2003, 38, 781.

17. Ahamed, M.J.; Chowdhury, D.A.; Uddin, M.N.; Hossain, K.J.; Choudhury, M.D.A.; Jannat, T. Pak. J. Anal. Chem. 2004, 5, 48.

18. Sreeja, P.B.; Sreekanth, A.; Nayar, C.R.; PrathapachandraKurup, M.R.; Usman, A.; Razak, I.A.; Chantrapromma, S.; Fun, H.K. J. Mol. Struc. 2003, 645, 221.

19. Salam, M.A.; Chowdhury, D.A. Bull. Pure Appl. Sci. 2001, $20,89$.

20. Vogel, A.I. A Text Book of Quantitative Inorganic Analysis, 3rd ed., Longmans: London; 1975; p 540.

21. Baliger, R.S.; Revankar, V.K. J. Serb.Chem. Soc. 2006, 71, 1301.

22. Hueso-Urena, F.; Illan-Cabeza, N.A.; Moreno-Carretero, M.N.; Penans Chamorro, A.L., Acta Chem. Solv. 2000, 47, 481.

23. Narang, K.K.; Aggarwal, A. Inorg. Chim. Acta 1974, 9, 137.

24. Chandra, S.; Tyagi, M.; Refat, M. J. Ser. Chem. Soc. 2009, 74, 907.

25. Blout, E.R.; Fields, M.; Karplus, R. J. Am. Chem. Soc. 1948, 70, 194.

26. Natrajan, R.; Antonysamy, K.; Thangaraja, C. Transition Met. Chem. 2003, $28,29$.

27. Munde, A.S.; Jagdale, A.N.; Jadhav, S.M.; Chondhekar, T.K. J. Korean Chem. Soc. 2009, $53,415$.

28. Natrajan, R.; Antonysamy,K.; Thangaraja, C. Transition Met. Chem. 2003, 28, 29.

29. Raman, N.; Pitchaikaniraja, Y.; Kulandaisamy, A. Proc. Indian Acad. Sci (Chem. Sci.) 2001, $113,183$.

30. Satpathy, K.C.; Panda, A.K.; Mishra, R.; Pande, I. Transition Met. Chem. 1991, 16, 410

31. Shoemaker, D.P.; Garland, C.W. Experiments in Physical Chemistry, 5th ed., McGraw-Hill: New York; 1989; pp 17-27.

32. Agrawal, R.K.; Garg, R.K.; Sindhu, S.K. J. Iranian Chem. Soc. 2005, 2, 203.

33. Horowitz, H.H.; Metzger, G.; Anal. Chem. 1963, 35, 1464.

34. Coats, A.W.; Redferm, J.P. Nature 1964, 201, 68.

35. El-Awad, A.M. J. Therm. Anal. Cal. 2000, 61, 197.

36. Impura, A.; Inoue, Y.; Yasumori, I. Bull. Chem. Soc. Jpn. 1983, 56, 2203.

37. Mane, P.S.; Shirodkar, S.G.; Arbad, B.R.; Chondhekar, T.K. Indian J. Chem. 2001, 40, 648.

38. Venketeswar, R.P.; Venkta, N.A. Indian J. Chem. 2003, 42, 896.

39. Mishra, L.; Singh, V.K. Indian. J. Chem. 1993, 32, 446. 